\title{
IMPLEMENTASI PERATURAN WALIKOTA BATAM NO 7 TAHUN 2014 TENTANG PENGARUSUTAMAAN GENDER DI KOTA BATAM TAHUN 2016
}

\author{
Nurhayati ${ }^{1}$, Muhammad Yasir ${ }^{2}$ \\ ${ }^{1}$ Program Studi Ilmu Pemerintahan, Fakultas Ilmu Sosial dan Ilmu Politik, Universitas Riau Kepulauan, \\ Indonesia \\ nurhayati@fisip.unrika.ac.id \\ ${ }^{2}$ Program Studi Ilmu Pemerintahan, Fakultas Ilmu Sosial dan Ilmu Politik, Universitas Riau Kepulauan, \\ Indonesia \\ yasir05@yahoo.co.id
}

\begin{abstract}
Abstrak
Pengarusutamaan gender (PUG) merupakan strategi yang dilakukan secara rasional dan sistematis untuk mencapai kesetaraan dan keadilan gender dalam sejumlah aspek kehidupan manusia melalui kebijakan dan program yang memperhatikan pengalaman, aspirasi, kebutuhan dan permasalahan perempuan dan laki-laki kedalam perencanaan, pelaksanaan, pemantauan dan evaluasi dari seluruh kebijakan dan program di berbagai bidang kehidupan dan pembangunan sesuai Intruksi Presiden Nomor 9 Tahun 2000 tentang pengarusutamaan gender dalam pembangunan Nasional dan Peraturan Menteri Dalam Negeri Nomor 15 Tahun 2008 tentang pedoman umum pelaksanan pengarusutamaan gender di daerah. Untuk pelaksanaan PUG di Kota Batam, pemerintah daerah harus melakukan koordinasi dengan Satuan Kerja Perangkat Daerah dalam hal ini adalah pemerintah. Pemerintah sebagai lembaga yang mengurusi dan bertanggung jawab akan pelaksanaan PUG di Kota Batam untuk mewujudkan kesejahteraan gender antara laki-laki dan perempuan salah satunya permasalahan perempuan, ketimpangan hak dan kewajiban laki-laki dan perempuan dalan berbagai aspek khususnya Sosial. Solusi yang bisa diberikan dengan memberdayakan perempuan sebagai salah satu aspek penting dalam pembangunan. implementasi program dari PUG adalah mewujudkan Batam yang responsife gender dilihat dari tolak ukur yang di gunakan penulis (Edward III): komunikasi, Sumber Daya, disposisi dan struktur birokrasi, ungsur ini memiliki peranan penting dalam mewujudkan kesetaran gender khususnya di kota Batam.

Kata Kunci : Implementasi, Pengarustamaan Gender, Kota Batam.
\end{abstract}

\begin{abstract}
Abstact
Gender mainstreaming (PUG) is a strategy that is carried out rationally and systematically to achieve gender equality and justice in a number of aspects of human life through policies and programs that pay attention to the experiences, aspirations, needs and problems of women and men in planning, implementing, monitoring and evaluating of all policies and programs in various fields of life and development in accordance with Presidential Instruction No. 9 of 2000 concerning gender mainstreaming in national development and Minister of Home Affairs Regulation No. 15 of 2008 concerning general guidelines for the implementation of gender mainstreaming in the regions. For the implementation of PUG in Batam City, the local government must coordinate with the Regional Work Unit in this case the government. The government as an institution that deals with and is responsible for the implementation of PUG in the city of Batam to realize gender welfare between men and women, one of which is the problem of women, inequality of rights and obligations of men and women in various aspects, especially social. Solutions that can be provided by empowering women as an important aspect of development. The implementation of the program from PUG is to realize a gender responsive Batam seen from the benchmarks used by the author (Edward): communication, resources, disposition and bureaucratic structure, this function has an important role in realizing gender equality especially in the city of Batam.
\end{abstract}

Key Word: Implementation, Gender Mainstreaming, Batam City. 


\section{PENDAHULUAN}

Deskriminasi berdasarkan gender masih terjadi pada berbagai aspek kehidupan diseluruh dunia, meskipun fakta menunjukkan adanya kemajuan yang cukup pesat dalam kesetaraan gender pada beberapa dekade terakhir ini. Masalah yang menyangkut dimensi gender antara laki-laki dan perempuan mempunyai akses, kontrol, dan prioritas yang berbeda dalam pemenuhan hak-hak di berbagai bidang. Permasalahan lainnya yang terjadi selama ini cendrung melahirkan ketidaksetaraan dan ketidakadilan gender, berdasarkan konsep gender yang di paparkan kepala badan pemberdayaan perempuan yang merupakan proses peminggiran akibat perbedaan jenis kelamin yang mengakibatkan kemiskinan, subordinasi yang mana menilai peran jenis kelamin lain lebih rendah.

Perbedaan jenis kelamin dalam jenjang jabatan juga berpengaruh terhadap gender, dimana kita dapat lihat di dinas pemberdayaan perempuan perlindungan anak dan keluarga berencana kota batam, dimana laki-laki hanya menduduki 1 jabatan di tingkat struktural organisasi, dimana selebihnya di duduki oleh perempuan, ini disebabkan oleh masih kurangnya pengetahuan tentang pengarusuutamaan gender di dina tersebut, padahal seperti yang kita ketahui, dinas pemeberdayaan perempuan perlindungan anak dan keluarga berencana ditunjuk langsung oleh pemerintah untuk menjalankan peraturan walikota batam no 7 tahun 2014 tentang PUG namun yang terjadi masih didapatkan stereotip dimana lakilaki dan perempuan dalam jabatan struktural tidak setara, dimana deskriminasi terjadi karena perbedaan jenis kelamin dan perbedan peran secara sosial.

Kebijakan mengenai kesetaraan dan ketidakadilan di rumuskan berdasarkan data yang terpilih atau data-data melihat perbandingan antara laki-laki dan perempuan di bidangbidang yang telah di tentukan, seperti pendidikan, kesehatan, ekonomi, dan sosial politik. Dari akar permasalahan ketidak adilan gender tersebut memunculkan konsep kesetaraan gender dalam poroses di dinas pemberdayaan perempuan. Keberhasilan pembangunan yang di laksanakan oleh pemerintah, swasta maupun masyarakat sangat tergantung pada peran serta seluruh penduduk baik laki-laki maupun perempuan (Kesetaraan Gender) selain sebagai pelaku Perempuan dan laki-laki sebagai pemanfaat hasil akhir dari pembangunan (Widjajanti, 2012: 14). 
Pengarusutamaan gender merupakan strategi yang dilakukan secara rasional dan sistematis untuk mencapai kesetaraan dan keadilan gender dalam sejumlah aspek kehidupan manusia melalui kebijakan dan program yang memperhatikan pengalaman, aspirasi, kebutuhan dan permasalahan perempuan dan laki-laki kedalam perencanaan, pelaksanaan, pemantauan dan evaluasi dari seluruh kebijakan dan program di berbagai bidang kehidupan dan pembangunan sesuai Intruksi Presiden Nomor 9 Tahun 2000 tentang pengarusutamaan gender dalam pembangunan Nasional dan Peraturan Menteri Dalam Negeri Nomor 15 Tahun 2008 tentang pedoman umum pelaksanaan pengarusutamaan gender di daerah.

Badan pemberdayaan perempuan perlindungan anak dan keluarga berencana adalah salah satu badan yang mempunyai tugas pokok melaksanakan penyusunan dan pelaksanaan kebijakan implementasi urusan pemerintah daerah di bidang pemberdayaan perempuan. Pengarusutamaan gender merupakan salah satu strategi yang di bentuk Pemerintah dalam rangka menangani permasalahan ketidakadilan gender. di kota Batam strategis pengarusutamaan gender belum di implementasikan secara maksimal hal ini masih terlihat dari semakin meningkatanya jumlah kasus kekerasan terhadap perempuan di Kota Batam. Dalam acara rapat koordinasi pemberdayaan perempuan Nurmadiah selaku kepala dinas pemberdayaan perempuan mengatakan bahwa kaum perempuan di Kota Batam khususnya di dinas Pemberdayaan Perempuan masih terhimpit beberapa permasalahan dibidang ekonomi khususnya tingkat partisipasi angkatan kerja nilainya masih rendah yaitu 30,3\% dibandingkan dengan laki-laki sebesar 58,9\%, sedangkan untuk tingkat pengangguran terbuka perempuan memiliki nilai 9,4\%, laki-laki mencapai angka 7,4\% (Dinas Pemberdayaan Perlindungan Anak Keluarga Berencana, 2017).

Secara normatif permasalahan yang terjadi di Dinas Pemberdayaan Perempuan adalah ditemuinya stereotip dimana tidak terdapat kesetaraan antara perempuan dan lakilaki di tingkat jenjang pendidikan, dimana tingkat pendidikan perempuan lebih tinggi dari pada laki-laki. Pada Dinas Pemberdayaan Perempuan juga masih ditemukan ketidaksetaraan gender pada jenjang struktural, dimana laki-laki hanya mengisi satu jabatan pada tingkat jabatan struktural, sedangkan perempuan lebih dominan pada jenjang structural sehingga terjadi ketidak setaraan gender pada Dinas Pemberdayaan perempuan. Tingkat jabatan struktural di Dinas Pemberdayaan Perempuan. 
Kondisi dari kesenjangan dari nilai angka tersebut juga merupakan cerminan dari kondisi yang terjadi di dinas pemberdayaan perempuan perlindungan anak keluarga berencana, di mana nilai dari angka-angka tersebut menunjukan masih adanya perbedaan manfaat yang di terima oleh laki-laki dan perempuan dalam hal mengakses pendidikan maupun jabatan struktural.

Atas dasar implementasi pemerintah diatas mendorong penulis untuk lebih dalam meneliti tentang pemberdayaan perempun dan langka-langka apa yang diambil untuk meningkatkannya. Dalam penelitian ini penulis mengambil studi kasus di bagian kantor dinas pemberdayaan perempuan perlindungan anak dan keluarga berencana kota Batam karena bagian ini yang menagani segala implementasi kebijakan yang berkaitan dengan pengarusutaman gender. Melalui pengarusutamaan gender, pemerintah dapat bekerja lebih efisien dan efektif dalam memproduksi kebijakan publik yang adil dan responsive gender untuk perempuan dan laki-laki. Kebijakan dan pelayanan publik serta program dan perundang-undangan yang adil dan responsive gender akan mambuahkan manfaat.

Keadilan dan kesetaraan gender menghendaki bahwa laki-laki dan perempuan mempunyi kesempatan yang sama untuk ikut serta dalam proses pembangunan, akses yang sama terhadap pelayanan serta memiliki status sosial dan ekonomi yang seimbang. Pengimplementasian strategi yang terkait dalam pengarusutamaan gender, pemberdayaan perempuan di berbagai sektor pembangunan, sejak dulu hingga kini dan kedepannya, pemerintah Kota Batam bakal tetap berkomitmen dalam sektor program pengarusutamaan gender yang dapat kita lihat dengan membuat regulasi terkait program-program yang telah di laksanakan di dinas pemerintah Kota Batam. Meskipun sampai saat ini telah banyak kemajuan pembangunan yang telah tercapai, namun pada kenyataannya kesenjangan gender masih terjadi di di Dinas Pemberdayaan Perempuan.

\section{TINJAUAN PUSTAKA}

\section{Implementasi}

Dengan mengacu pada konsep kebijakan yang di kemukakan James Anderson bahwa kebijakan merupakan arah tindakan yang mempunyai maksud yang di tetapkan oleh seorang aktor atau sejumlah aktor dalam mengatasi suatu masalah atau suatu persoalan maka dapat di 
ketahui bahwa kebijakan (dalam hal ini berarti kebijakan publik) timbul karna adanya suatu masalah yang berkaitan dengan publik (Purwanto dan Sulistyastuti, 2012: 31). Adapun kata "publik" menurut Thomas dye mengandung tiga konotasi yaitu pemerintah, masyarakat dan umum (Winarno, 2012: 27).

Implementasi adalah tindakan-tindakan yang dilakukan baik oleh individu-individu atau pejabat-pejabat atau kelompok-kelompok pemerintah atau swasta yang diarahkan pada tercapaianya tujuan-tujuan yang telah digariskan dalam keputusan kebijakan1. Model yang di tawarkan Van meter dan Van horn ini mempunyai enam variable yang membentuk ikatan (linkage) antara kebijakan dan pencapaian (Pervormance). Variabel tersebut di jelaskan sebagai berikut (Purwanto dan Sulistyastuti, 2012: 92):

a. Ukuran dasar dan tujuan kebijakan

Variable ini didasarkan kepentingan utama terhadap faktor-faktor yang menentukan pencapaian kebijakan. Indikator-indikator pencapaian ini menilai sejauh mana ukuran-ukuran dasar dan tujuan-tujuan kebijakan telah di realisasikan. Ukuranukuran dasar dan tujuan-tujuan berguna di dalam menguraikan tujuan-tujuan keputusan kebijakan secara menyeluruh. Disamping itu, ukuran dasar dan tujuan-tujuan merupakan bukti itu sendiri dan dapat di ukur dengan mudah dalam beberapa kasus.

b. Sumber-sumber kebijakan

Sumber-sumber layak mendapatkan perhatian karna menunjang keberhasilan implementasi kebijakan. Sumber-sumber yang di maksud mencangkup dana atau perangsang (Insentif) lain yang mendorong dan memperlancar implementasi yang efektif.

c. Komunikasi antar organisasi dan kegiatan-kegiatan pelakssanaan

Komunikasi di dalam dan antara organisasi-organisasi merupakan suatu proses yang kompleks dan sulit. Dalam meneruskan pesan-pesan kebawah dalam suatu organisasi ke organisasi lainnya, para komunikator dapat menyimpannya atau menyebar luaskannya, baik secara sengaja atau tidak sengajah.

d. Karakteristik badan-badan pelaksana 
Pembahasan mengenai karakteristik badan-badan pelaksana ini tidak bisa lebas dari struktur birokrasi. Struktur birokrasi di artikan sebagai karakteristik-karakteristik, norma-norma dan pola-pola hubungan yang terjadi berulang-ulang dalam badan eksekutif yang mempunyai hubungan baik potensial maupun nyata denganapa yang mereka milikidengan menjalankan kebijakan.

Pengertian Implementasi menurut George Edward III (Purwanto dan Sulistyastuti, 2012: 92) adalah:

" policy implementation as we have seen is the stage of policy making between the establishment of policy such as the passage of a legislative act, the issuing of an execuitive order, the handing down of a judicial decision, or the policy for the people whom it affects".

Jadi implementasi itu merupakan tindakan-tindakan yang dilakukan oleh pemerintah untuk mencapai tujuan yang telah ditetapkan dalam suatu keptusan kebijakan. Akan tetapi pemerintah dalam membuat kebijakan juga harus mengkaji terlebih dahulu apakah kebijakan tersebut dapat memberikan dampak yang buruk atau tidak masyarakat. Hal tersebut bertujuan agar suatu kebijakan tidak bertentangan dengan masyarakat apalagi sampai merugikan masyarakat.

Menurut Georgi Edward III (Wahab, 2017: 17) berpandang bahwa implementasi kebijakan di pengaruhi oleh empat variable, yaitu:

a. Komunikasi, yaitu keberhasilan implementasi kebijakan mensyaratkan agar implementator mengetahui apa yang harus di lakukan, dii mana yang menjadi tujuan dan sasaran kebijakan harus dittransmisikan kepad kelompok sasaran (target group), sehingga akan mengurangi distorsi implementasi. Pengetahuan atas apa yang akan mereka kerjakan baru dapat berjalan dengan baik, sehingga setiap keputusan kebiajakn dan peraturan implementasi harus ditransminsikan , kebijakan yang dikomunikasikan harus tepat, akurat dan konsisten.

b. Sumber daya, meskipun isi kebijakan telah di komunikasikan secara jelas dan konsisten, tetapi apabila implementator kekurangan sumberdaya untuk melaksanakan, maka implementasi tidak akan berjalan efektif. Sumber daya tersebut dapat berwujud sumberdaya manusia misalnya kompetensi implementor dan sumberdaya financial. Indikator-indikator yang digunakan untuk melihat 
sejauhmana sumberdaya dapat berjalan dengan baik dan rapi, yaitu staf, informasi, wewenang dan fasilitas

c. Disposisi, adalah watak dan karakteristik yang di miliki oleh implenentor, seperti komitmen, kejujuran, sifat demokratis. Apabila implementator memiliki disposisi yang baik, maka implementator tersebut dapat menjalankan kebijakan dengan baik seperti yang di inginkan oleh pembuat kebijakan ketika implementator memiliki sikap yang berbeda dengan pembuat kebijakan, maka proses implementasi kebijakan juga menjadi tidak efektif. Variabel disposisi adalah pengangkatan birokrat dan insentif

d. Struktur Birokrasi, struktur organisasi yang bertugas mengimplementasikan kebijakan memiliki pengaruh yang signifikan terhadap implementasi kebijakan. Aspek dari struktur organisasi adalah Standar Operating Procedure (SOP) dan Frakmeentasi. Struktur organisan yang terlalu panjang akan endrung melemahkan pengawasan dan menimbulkan Red-tape, yaini prosedur birokrasi yang rumit dan kompleks, yang menjadikan aktifitas birokraasi tidak fleksibel.

\section{a. Pengarusutamaan Gender}

Istilah gender dipahami secara berbeda-beda oleh masyarakat. Pada dasarnya, gender adalah salah satu konsep sosial yang dikonstruksikan seiring dengan berkembanganya persoalan sosial yang terkait dengan relasi laki-laki dan perempuan dalam ruang lingkup buada, tradisi, norma, dan pemahaman dari suatu agama. Menurut Mansour Fakih (1999: 71) Terdapat tiga paham untuk bisa memahami teori gender yaitu nature (konstruksi budaya), nature (secara alamiah) dan equilibrium (keseimbangan atau kemitraan).

Konsep gender sendiri bersal dari bahasa latin 'Genus' yang bermakna jenis atau tipe. Kata gender dalam bahasa Indonesia merupakan kata serapan dari bahasa inggris Gender yang bermakna 'sex' atau jenis kelamin (Handayani, 2008: 83). Akan tetapi, kedua istilah ini berbeda makna. Istilah gender lebih mengacu sebagai suaptu konstruksi sosial budaya yang membedakan pria dan wanita, sedangkan sex lebih mengacu pada perbedaan pria dan wanita dari sudut biologis. Sementara itu, menurut Oakley, gender adalah perbedaan perilaku antara laki-laki dan perempuan yang di 
konstruksi secara sosia,yaini perbedaan kodrat atau bukan ketentuan tuhan yang maha esa melainkan di ciptakan oleh manusia (laki-laki dan perempuan) melalui proses sosial dan Kultural yang panjang (Kantor Menteri Negara Pemberdayaan Perempuan RI, 2001: $71)^{2}$

Hubeis gender adalah suatu konsep yang menunjukan pada suatu konsep yang menunjuk pada suatu sistem peranan dan hubungan antara perempuan dan laki-laki yang tidak di tentukan perbedaan biologis, akan tetapi di tentukan oleh lingkungan, sosial, politik dan ekonomi.

\section{METODELOGI}

Metode penelitian mengunakan penelitian kualitatif. Bogdan \& Taylor dalam Moleong (2007: 4) mendefinisikan metode kualitatif sebagai prosedur penelitian yang menghasilkan data deskriptif berupa katakata tertulis atau lisan dari orang-orang dan perilaku yang dapat diamati. Penelitian ini berlokasi di Kota Batam. Teknik pengumpulan data yang digunakan adalah observasi, wawancara dan dokumentasi. Instrumen penelitian yang digunakan dalam penelitian ini adalah peneliti sendiri, pedoman wawancara, alat perekam dan alat tulis. Analisis data dalam penelitian ini menggunakan Model Interaktif menurut Miles dan Hubberman dalam Sugiyono (2011: 224). Analisis model interaktif tersebut, terdiri dari pengumpulan data, reduksi data, penyajian data, dan penarikan kesimpulan.

\section{PEMBAHASAN}

Kebijakan pengarusutamaan Gender (PUG) merupakan strategi untuk menjamin bahwa seluruh proses perencanaan, pelaksanaan, monitoring dan evaluasi dari seluruh kebijakan program dan projek diseluruh sektor pembangunan telah memperhitungkan dimensi dan aspek gender yaitu laki-laki dan perempuan sebagai pelaku atau objek dan subjek yang setara dalam akses, partisipasi dan kontrol atas pembangunan serta dalam memanfaatkan hasil pembangunan.

Dinas Pemberdayaan Perempuan Perlindungan Anak dan Keluarga Berencana sebagai lembaga yang berfungsi sebagai pelaksana kewenagan Walikota Batam No.7 Tahun 2014 tentang Pengarusutamaan Gender, memiliki kewenagan dekosentrasi serta tugas pembantuan

\footnotetext{
${ }^{2}$ Kantor Menteri Negara Pemberdayaan Perempuan Republik Indonesia dan Women Support

Project II Gender dan Pembangunan, 2001. Hal 71
} 
yang diberikan oleh pemerintah. Sudah semestinya memahami gender beserta subtansinya, dan merumuskan kebijakan yang sesintif gender dalam setiap program beserta kegiatan yang dilakukan.

\section{Komunikasi}

Konsep komunikasi pada implementasi kebijakan pada umumnya menganalisa apakah pessan yang di kirimkan komunikator kebijakan dapat di terima dan di pahami dengan baik oleh komunikan kebijakan. Jika pesan yang di kirim dapat di terima secara engkap, maka komunikasi di sebut evektif. Pada perkembangan komunikasi kebijakan saat ini mengatakan bahwa komunikasi di sebut efektif mana kala pesan dari tujuan kebijakan yang di sampaikan komunikator bukan saja bisa di terima dengan jelas, melainkan juga mempengaruhi dan di laksanakan oleh komunikan.

Komunikasi memegang peranan yang sangat penting dalam kesuksesan suatu kebijakan termasuk implementasi kebijakan Pemerintah Kota Batam dalam Peraturan Walikota Batam dalam Pengarusutamaan Gender di Kota Batam No.7 Tahun 2014 tentang Pengarusutamaan Gender di Kota Batam Tahun 2016. Sebagai mana di kemukakan oleh Edward III bahwa komunikasi di artikan sebagai" proses penyampaian informasi komunikator kepada komunikan”. Informasi mengenai kebijakan Publik menurut Edward III perlu di sampaikan dan di sosialisasikan pada pelaku kebijakan agar para pelaku kebijakan dapat mengetahui apa yang harus mereka periapkan dan mereka lakukan untuk menjalankan ebijakan tersebut sehingga tujuan dan sasaran kebijakan dapat di ccapai secara yang di harapkan.

\section{a. Sosialisasi kebijakan}

Sosialisasi adalah penyebar luasan informasi (Program, Peraturan Kebijakan) dari satu pihak (Pemilik Program) ke pihak lain (Masyarakat umum) di mana di harapkan dapat menumbuhkan kesadaran, menumbuhkan perubahan sikap, dan perilaku masyarakat. Oleh sebab itu, sosialisasi harus terintegrasi dalam aktivitas pelaksanaan kebijakan yang di lakukan secara terus menerus untuk menumbuhkan sikap kesadaran masyarakat dalam pelaksanaan dari suatu kebijakan yang telah di keluarkan oleh pembuat kebijakan secara terus menerus dan berkesiambungan. 
Adapun tujuan sosialisasi secara umum adalah mengupayakan masyarakat luas memahami dan mampu menginternalisasikan makna dari konsep dan tujuan dari kebijakan pemerintah, masyarakat luas mengetahui dan memahami perkembangan pelaksana kebijakan yang di keluarkan oleh pemerintah sedangkan secara khusus adalah agar terdapatnya komitmen dan kerjasama antara pemerintah dengan masyarakat untuk merencanakan, melaksanakan dan memonitor-mensupervis secara bersama-sama, dapat merangssang minat kelompok strategis dan kelompok peduli untuk melakukan tindakan baik dalam kerjasama maupun membangun pengawasan berbasis masyarakat.

pemerintah Kota Batam telah mensosialisasikan tentang kebijakan pengarusutamaan gender kepada Dinas pemberdayaan Perempuan perlindungan anak dan keluarga berencana kota Batam. hal ini di lakukan agar dinas pemberdayaan perempuan perlindungan anak dan keluarga berencana kota Batam dalam pelaksanaannya nanti tidak mengalami kesulitandan mendapatkan permasalahan yang akan mengganggu proses pelaksanaannya. sosialisasi suatu kebijakan dari para pembuat kebijakan dalam hal ini adalah pemerintah daerah Kota Batam telah berhasil di lakukan dan kelompok pelaksana dari kebijakan itu adalah dinas pemberdayaan Perempuan Perlindungan anak dan Keluarga Berencan Kota Batam juga telah memahami kersebut.

\section{b. Manfaat Kebijakan}

Tujuan dari kebijakan adalah untuh memecahkan massalah atau mencara sosusi alternatife dari masalah yang menjadi isu bersamyang berkembang di dinas. Oleh karna itu tidak semua masalah yang berkembang di masyarakat bisa melahirkan suatu kebijakan, hanya masalah Publik yang dapat menggerakan orang banyak untuk ikut memikirkan dan mencari solusi yang bisa menghasilkan suatu kebijakan publik.

kebijakan yang di keluarkan oleh pemerintah daerah Kota Batam sangat bermanfaat dari pembangunan Kota Batam yang responsif gender dan terkhususnya bagi para pegawai atau tenaga kerja di dinas pemberdayaan perempuan perlindungan anak dan keluarga berencana kota batam. dengan adanya kebijakan ini maka dinas pemberdayaan perempuan perlindungan anak da keluarga berencana kota batam harus patuh dan tunduk terhadap ketentuan yang berlaku. 


\section{Sumberdaya}

Menurut Edward III sumber daya (Resources) memiliki posisi yang sangat penting dalam keberhasilan implementasi kebijakan. Selanjutnya Edward III mengatakan bahwa apabila para pelaksana (Implementots) kekurangan sumber-sumber yang di perlukan untuk menjalankan kebijakan, maka implementasi tersebut tidak akan menjadi efektif, walaupun perintah Implementasi di tranmisikan dengan akurat, jelas, dan konsisten. Sumberdaya ini akan di lihat dari aparatur, anggaran dan fasilitas kebijakan yaitu:

\section{a. Aparatur/Staf}

Hal ini di perkuat dengan wawancara Roswita, SE. selaku Sub Bidang Pemberdayaan aktivitas Gender dinas pemberdayaan perempuan perlindungan anak dan keluarga berencana kota Batam terkait dengan sumberdaya yang ada dalam pelaksanaan peraturan wali Kota Batam No.7 Tahun 2014 Tentang Pengarusutamaan Gender di Dinas Pemberdayaan Perempuan perlindungan anak dan keluarga berencana Kota batam, dinas pemberdayaan perempuan perlindungan anak dan keluarga berencana kota batam masih belum maksimal dalam mengimplementasikan pengarusutamaan gender di kantor akibat dari sumber daya manusia dan sumber daya anggaran. Hal ini perlu menjadi perhatian darin pemerintah kota Batam agar masalah PUG di dinas pemberdayaan perempuan perlindungan anak dan keluarga berencana kota batam dapat berjalan dengan baik.

\section{b. Wewenang}

Wewenang adalah hal untuk melakukan sesuatu atau memerintah orang lain untuk melakukan atau tidak melakukan agar melakukan sesuatu agar mencapai tujun tertentu. penetapan wewenang sudah cukup baik sesuai dengan pengarusutamaan gender tidak membedakan peran laki-laki dan perempuan, walaupun di dinas pemberdayaan perempuan, perempuan lebih dominan dari pada laki-laki hal tersebut tidak menjadi penghalang dalam penempaan wewenang.

\section{c. Fasilitas}

Fasilitas adalah segala sesuatu yang dapat memudahkan dan dapat melancarkan pelaksanaan suatu usah baik di pemerintah maupun swasta. Sesuatu yang dapat 
memudahkan dan melancarkan suatu usaha tersebut biasanya berupa benda-benda. Fasilitas yang berupa benda yang dapat di bendakan, yang mempunyai peranan dapat memudahkan dan melancarkan suatu usaha yang biasanya di perlukan sebelum suatu kegiatan berlangsung.

Beberapa program tersebut adalah fasiitas pengembangan Pusat Pelayanan Terpadu Pemberdayaan Perempuan dan Anak (P2TP2A), Pelaksanaan Peogram Peningkatan Peran Wanita Menuju Keluarga Sehat Sejahtera (P2WKSS), Penentuan potensi organisasi dan lembaga masyarakat pemberdayaan perempuan. Dimana dalam program-program tersebut melibatkan partisipasi perempuan dan laki-laki secara penuh untuk mencapai terwujudnya kesetaraan dan keadilan Gender.

Surat keputusan pembentuk kelompok kerja (Pokja) Pengarusutamaan Gender (PUG) di Kota Batam baru dibuat tahun 2010. Berdasarkan data yang diperoleh peneliti dari asisten bagian hukum pemerintahanan dinas Pemberdayaan Perempuan Perlindungan Anak dan Keluarga Berencana sudah didiberikan surat keputusan untuk pembentukan pokja yaitu keputusan Walikota Batam Nomor:89/Kep.217-Huk.Org/2014 tentang pembentukan Kelompok Kerja (Pokja) Pengarusutamaan Gender (PUG).

Berdasarkan wawancara di atas peneliti menganalisis mengenai hal adanya Surat Keputusan Pembentukan Kelompok Kerja (Pokja) Pengaruutamaan Gender (PUG) di Kota Batam perempuan dan laki-laki dilibatkan dengan adanya program-program lintas sektoral di unit Instansi Pemerintahan yang memang terkoordinasi di Badan Pemberdayaan Perempuan. Selama melakukan penelitian ini, berdasarkan hasil wawancara kepada beberapa sumber, aspek pengarusutamaan gender ini sangat luas mencangkup segala aspek kehidupan masyarakat.

Berdasarkan hasil wawancara di atas peneliti dapat mengetahui bahwa pengarusutamaan gender itu menyangkut banyak aspek yaitu: Pendidikan, Kesehatan, Ekonomi, Organisasi Politik dan Hukum Serta pengarusutamaan gender seharusnya ada di setiap instansi pemerintahan Kota hanya saja lebih berfokus hanya pada badan pemberdayaan perempuan perlindungan anak dan keluarga berencana dan berdasarkan studi dokumentasi yang peneliti lakukan ternyata penguatan pengarusutamaan gener terbagi berdasarkan data terpilah yaitu, data yang berdasarkan jenis kelamin (Sex-Disaggregated 
data) adalah data yang di kumpulkan dan di presentasikan berdasarkan jenis kelamin, Lakilaki dan Perempuan, anak laki-laki dan anak perempuan.

\section{Disposisi}

Disposisi adalah sikap seorang terhadap sesuatu yang di pengaruhi oleh adat, sikap, emosi, nilai,etika, kekuasaan, persuasi, dan atau genetika. Menurut Edwar III disposisi merupakan salah satu faktor yang mempengaruhi konsekuensi penting bagi implementasi kebijakan yang penting. Jika para pelaksana mempunyai sikap positif atau adanya dukungan terhadap implementasi kebijakan maka kemungkinan besar implementasi kebijakan akan terlaksana sesuai dengan putusan awal. Demikian sebaliknya, jika para pelaksana bersikap negatif dan atau menolak terhadap implementasi kebijakan karna konflik kepentingan maka implementasi kebijakan akan menghadapi kendala yang serius.

Sikap positif atau adanya dukungan dari pelaksana kebijakan berperan penting dalam mewujudkan implementasi kebijakan yang sesuai dengan tujuan atau sasaran. Karakter penting yang harus di miliki oleh pelaksana kebijakan misalnya kejujuran dan komitmen yang tinggi. Kejujuran mengarahkan implementator untuk tetap berada dalam asa program yang telah di gariskan, sedangkan komitmen yang tinggi dari pelaksana kebijakan akan membuat mereka selalu antusias dalam melaksanakan tugas, wewenang, dan tanggung jawab sesuai dengan peraturan yang telah di tetapkan.

\section{a. Pengangkatan Birokrasi}

Sikap dari pelaksana kebijakan akan sangat berpengaruh dalam implementasi kebijakan apabila implementator memiliki sikap yang baik maka dia akan mendapatkan menjalankan kebijakan dengan baik seperti apa yang di inginkan. Berdasarkan wawancara di atas dapat di lihat bahwa pengangkatan birokrat di Dinas pemberdayaan perempuan perlindungan anak dan keluarga berencana dalam implementasi kebijakan Peraturan Walikota Batam Nomor 7 Tahun 2014 tentang pengarusutamaan gender, pengangkatan birokrat tersebut dapat di wujudkan dalam kinerja setiap masing-masing pegawai yang ada di dinas tidak ada perbedaan pengangkatan birokrat baik pegawai laki-laki maupun perempuan dan pengangkatan birokrat di dinas pemberdayaan perempuan dan perlindungan anak dan keluarga berencana kota batam sudah cukup baik dan sesuai dengan implementasi kebijakan pengarusutamaan gender.

\section{b. Insentif}


Insentif mereupakan sarana motivasi yang mendorong para karyawan untuk bekerja dengan kemampuan yang optmal, yang dimaksudkan sebagai pendapatan ekstra di luar gaji atau upah yang telah ditentukan. Pemberian insentif dimaksudkan agar dapaat memenuhi kebutuhan para karyawan dan keluarga mereka. Seperti kata Samsudin insentif adalah pemberian upah atau gaji yang berbeda, bukan didasarkan pada evaluasi jabatan, namun karena adanya perbedaan prestasi kerja (Samsudin, 2010: 194).

Sistem insentif merupakan bentuk kompensasi tetapi yang disebut sistem kompensasi berdasarkan kinerja (Pay for performance plan). Sistem kompensasi dibuat dan diatur untuk mencapai tujuan-tujuan tertentu (Newman dan Milkovich, 2008: 7). Tujuan-tujuan tersebut meliputi efisiensi (Efficiency), keadilan (Equity), dan kelayakan (Compliance) sesuai hukum dan perundang-undangan yang berlaku.

pemberian insentif atau kompentatif kepada pegawai birokrat di Dinas pemberdayaan perempuan perlindungan anak dan keluarga berencana dalam implementasi kebijakan Peraturan Walikota Batam Nomor 7 Tahun 2014 tentang pengarusutamaan gender, insetif tersebut dapat di wujudkan dalam kinerja setiap masing-masing pegawai yang ada di dinas hanya saja tingkat nilai yang didapat sesuai dengan bidang pegwai baik pegawai laki-laki maupun perempuan dan pemberian insentif di dinas pemberdayaan perempuan dan perlindungan anak dan keluarga berencana kota batam sudah cukup baik dan sesuai dengan implementasi kebijakan pengarusutamaan gender.

\section{Struktur birokrasi}

Struktur Birokrasi adalah pembagian tugas dan tanggung jawab kepada masingmasing aparatur dinas pemberdayaan perempuan perlindungan anak dan keluarga berencana kota batam yang terlibat dalam implementasi peraturan walikota No 7 tahun 2014 tentang pengarusutamaan gender di kota batam khususnya di dinas pemberdayaan perempuan. Struktur birokrasi menjelaskan bagaimana kedudukan, tugas dan fungsi yang di alokasikan kepada setiap pegawai yang terlibat di d inas pemebrdayaan perempuan di kota batam.

Struktur birokrasi dari pelaksana kebijakan memiliki peranan penting dalam kebijakan peraturan walikota ini. Salah satu aspek yang terpenting dalam SKPD adalah adanya standar oprasional prosedur (SOP) dan frakmentasi atau penyebaran tanggung jawab. Berikut peneliti akan menjelaskan struktur birokrasi dalam implementasi peraturan Walikota ini melalui dua indikator tersebut yaitu: 


\section{a. Fragmentasi}

Struktur birokrasi merupakan salah satu faktor yang berpengaruh terhadap dan fungsi yang dialokasikan dalam organisasi. Hal ini mempunyai dampak yang signifikan terhadap cara sikap aparatur melaksanakan tugasnya dalam implementasi implementasi kebijakan. Struktur birokrasi menjelaskan bagaimana kedudukan, tugas kebijakan. Ketika arah dan strategi di Dinas Pemberdayaan Perempuan Perlindungan Anak dan Keluarga Berencana Kota Batam secara keseluruhan telah ditetapkan serta struktur birokrasi telah dibentuk maka hal yang perlu diperhatikan adalah aparatur dari Dinas Pemberdayaan Perempuan Perlindungan Anak dan Keluarga Berencana Kota Batam melakukan dan menjalankan tugas dan fungsinya.

Fragmentasi atau penyebaran tanggung jawab yang terjadi didalam Implementasi Peraturan Walikota Batam tentang pengarusutamaan Gender di Kota Batam yang dilaksanakan oleh Dinas Pemberdayaan Perempuan Perlindungan Anak dan Keluarga Berencana akan terwujud melalui pola kinerja mereka yang saling bekerjasma untuk mensukseskan pelaksanaan Implementasi kebijakan Peraturan Walikota ini. Masing-masing pegawai dari pelaksana Implementasi kebijakan perwako ini dalam menjalankan tugas saling memabntu dan bekerjasama dengan baik. Hal itu dilakukan demi mencapai keberhasilan implementasi kebijakan Perwako ini guna meningkatkan kesadaran para pegawai di Dinas Pemberdayaan Perempuan Perlindungan Anak dan Keluarga Berencana melalu peraturan yang telah dibuat berdasarkan Pengarusutamaan Gender. Dinas Pemberdayaan Perempuan Perlindungan Anak dan Keluarga Berencana Kota Batam sebagai pelaksana Implementasi kebijakan Perwako ini dalam menjalankan tugsnya saling melengkapi dan mendukung dari masing-masing mereka, sehingga pola hubungan yang terjadi bersifat saling bekerjasama.

\section{b. Standar Operasional Prosedur (SOP)}

Salah satu aspek yang terpenting dalam birokrasi adalah adanya standar operasional prosedur (SOP). Menurut Moeikjat standar operasional prosedur daalah urutan langkahlangkah atau pelaksanaan-pelakasanaan pekerjaan dimana pekerjaan tersebut dilakukan, berhubungan dengan apa yang dilakukan, bagaimana melakukannya, bilaman melakukannya, dimana melakukannya, dan siapa yang melakukanna.

Sedangkan menurut Tjiptoatmoko standar operasional prosedur merupakan suatu pedoman atau acuan untuk melaksanakan tugas pekerjaan sesuai dengan fungsi dan alat penelian kinerja instansi pemerintah berdasarkan indikatot-indikator teknis, administratif dan 
prosedural sesuai tata kerja, prosedur kerja dan sistem kerja pada unit kerja yang bersangkuta, jadi Standar Operasional Prosedur adalah suatu standar atau pedoman tertulis yang dipergunakan untuk mendorong dan menggerakan Dinas Pemberdayaan Perempuan Perlindungan Anak dan keluarga Berencana Kota Batam untuk mencapai tujuan. SOP merupakan tata cara atau tahapan yang dibakukan dan harus dilalui untuk menyelesaikan suatu proses kerja tertentu.

\section{KESIMPULAN}

Berdasarkan pembahasan diatas maka dapat disimpulkan bahwa Implementasi Peraturan Walikota Batam No. 7 Tahun 2014 di Dinas Pemberdayaan Perempuan perlindungan anak dan keluarga berencana Kota Batam tentang pelaksanaan Pengarusutamaan Gender adalah sebagai berikut.

1. Komunikasi

Komunikasi sangat menentukan keberhasilan pencapaian tujuan dari implementatasi Peraturan Walikota No.7 Tahun 2014 Tentang Pengarusutamaan Geder di Kota Batam Tahun 2014. Komunikasi yang di lakukan adalah berupa sosialisasi yang di lakukan oleh pemerintah daerah Kota Batam kepada seluruh SKPD yang ada di Kota Batam, sosialisasi yang di lakukan berjalan dengan lancer tanpa ada hambatan yang menghalanginya dan semua yang hadir dalam sosialisasi itu memahami dan mendukung sepenuhnya penerapan dari Peraturan wali Kota Batam No.7 Tahun 2014 tentang Pengarusutamaan Gender.

2. Sumber daya

Ketersediaan sumberdaya adalah merupakan salah satu faktor yang menunjang keberhasilan dari impleentasi Perturan wali Kota Batam No.7 Thun 2014 tentNG Pengarusutamaan Gender. Berdasarkan wawancara yang penlis lakukan terhadap beberapa orang narasumber dapat di simpulkan bahwa tim pelaksana terhadap implementasi Peraturan Walikota No.7 Tentang Pengarusutamaan Gender sangat kekurangan sumber daya manusia dan sumber dana, sehingga dalam pelaksanaan peraturan Walikota tersebut belum berjalan dengan efektif.

\section{Disposisi}

Disposisi merupakakan salah satu faktor yang mempunyai konsekuensi bagi implementasi kebijakan yang efektif. Jika paa pelaksan mempunyai sikap positif atau 
adanya dukungan terhadap implementasi kebijakan maka kemungkinan besar implementasi kebijakan akan terlaksan sesuai dengan keputusan awal. Demikian sebaliknya, jika para pelaksana bersikap negatif atau menolak terhadap implementasi kebijakan karna konflik kepentingan maka implementasi kebijakan akan menghadapi kendala yang serius. Berdasarkan wawancara yang penulis lakukan terhadap aparatur atau pegawai di Dinas Pemberdayaan Perempuan perlindungan anak dan keluarga berencana Kota Batam dapat di simpulkan bahwa disiplin pegawai dalam bekerja untuk tercapainya tujuan yang efektif dari peraturan Wali Kota Batam No.7 Tahun 2014 tentang Pengarusutamaan Gender di Dinas Pemberdayaan Perempuan perlindungan anak dan keluarga berencana Kota Batam pada Tahun 2016 sudah bagu dan juga para pegawainya mendapatkan insentif dari pemerintah derah Kota Batam, sehingga para pegawai mempunyai komitmen yang tinggi dan tetap konsisten untuk mencapai tujuan yang di harapkan dari pelaksanaan peraturan Walikota Batam No.7 Tahun 2014 tentang Pengarusutamaan Gender.

\section{Struktur Birokrasi}

Struktur birokrasi memiliki peranan peranan penting dalam kebijakan peaturan wali Kota Batam No.7 Tahun 2014 tentang Pengarusutamaan Gender pada tahun 2016. Salah satu aspek yang terpenting dalam struktur birokrasi ini adalah adanya frakmentasi atau penyebaran tanggung jawab dan Standar Oprasionan Prosedur (SOP). Berdasarkan wawancara penulis terhadap beberapa orang responden di Dinas Pemberdayaan Perempuan perlindungan anak dan keluarga berencana Kota Batam sudah cukup jelas dan semua sudah di tepati oleh masing-masing pegawai begitujuga dengan SOP nya juga telah ada, sehingga para pegawai bekerja sesuai dengan SOP tersebut. Jadi struktur birokrasi dalam implementasi Peraturan walikota Batam No.7 Tahun 2014 tentang Pengarusutamaan Gender di Kota Batam pada tahun 2016 sudah bagus.

\section{DAFTAR PUSTAKA}

Widjajanti. (2012). Penelitian dan Pengarusutama Gender: Sebuah Pengantar. LIPI.

Dinas Pemberdayaan Perempuan Perlindungan Anak Keluarga Berencana. (2017). Pengarusutamaan Gender. Diunduh di http://Sijorikepripasienkis.com pada hari Rabu 01 Maret 2017. 
Samsudin, Sadili. (2010). Manajemen Sumber Daya Manusia. Cetakan ke-3. Pustaka Setia.

Sugiyono. 2011. Metode Penelitian Kuantitatif Kualitatif dan $R \& D$. Bandung: Alfabeta.

Moleong, L.J. 2007. Metodologi Penelitian Kualitatif. Bandung: PT. Remaja Rosdakarya.

Newman dan Milkovich. (2008). Compensation. Newyork: The McGraw-Hill Company.

Purwanto, Erwan Agus dan Sulistyastuti, Dyah Ratih. (2012). Implemetasi Kebijakan Publik, Konsep, dan Aplikasinya di Indonesia. Yogyakarta: Gava Media.

Winarno, Budi. (2012). Kebijakan Publik Teori, Proses, dan Studi Kasus. Center for Academic Publishing Service : Yogyakarta.

Wahab, Solichin Abdul. (2017). Analisis Kebijakan dari Formulasi ke Penyususnan ModelModel Implementasi Kebijakan Publik. Bumi Aksara.

Fakih, Mansour . (1999). Analisis Gender dan Transformasi Sosial. Penerbit Pustaka Pelajar

Trisakti Handayani, Sugiarti. (2008). Konsep dan Teknik Penelitian Gender. UMM Press. Malang.

Kantor Menteri Negara Pemberdayaan Perempuan Republik Indonesia dan Women Support Project II. (2001). Gender dan Pembangunan.

\section{Produk Hukum}

Intruksi Presiden Nomor 9 Tahun 2000 tentang pengarusutamaan gender dalam pembangunan Nasional

Peraturan Menteri Dalam Negeri Nomor 15 Tahun 2008 tentang pedoman umum pelaksanaan pengarusutamaan 